\title{
Implementation of Constitutional Courts Decision on Illegitimate Children in Indonesia
}

\author{
Fuad Thohari \\ Syarif Hidayatullah \\ State Islamic University Jakarta, Indonesia \\ fuad.thohari@uinjkt.ac.id
}

\author{
Afwan Faizin \\ Syarif Hidayatullah \\ State Islamic University Jakarta, Indonesia
}

\begin{abstract}
The ruling of the Constitutional Court No. 46/PUUVIII/2010 concerning the status of illegitimate children where they have legal relation with their biological fathers receives numerous complaints from diverse religious judges. This is proved by the study of the religious judges' view in the region of DKI Jakarta and Banten regarding the court's decision. This research shows that the judges have two different views: first, Religious Court (PA) and High Religious Court (PTA) judges who accept the decision of the MK No. 46/PUU-VIII/2010 in the judicial structure as a court decision is final and binding. Both PA and PTA judges accept the decision of the CONSTITUTIONAL COURT No. 46/PUU-VIII/2010 under condition that the CONSTITUTIONAL COURT decision No. 46/PUUVIII/2010 is interpreted and understood in the context of sirri marriage in accordance with the provisions of the religion (Islam) in article 2 paragraph (1) of the marriage law of 1974. Second, the PA and the PTA Judges who reject the substance of the CONSTITUTIONAL COURT decision No. 46/PUU-VIII/2010 because the decision will open the opportunity to legalize adultery. The judges and the PTA PA then chose to use the principle of contralegem in its implementation, i.e. to override the existing positive law with an emphasis on the principle of the legal norms of life in the society, especially religious norms.
\end{abstract}

Keywords-Illegitimate Children; Legal Status; Constitutional Court Decision; Religious Judges; Sirri Marriage.

\section{INTRODUCTION}

In the year 2012, the history of Indonesia marriage law is tinged with an atmosphere of tension over the emergence of a ruling of the Constitutional Court (hereinafter abbreviated MK) of the Republic of Indonesia concerning inheritance of illegitimate children. The CONSTITUTIONAL COURT of the Republic of Indonesia has agreed to test the material Article 43 paragraph (1) of law number 1 Year 1974 about marriage (hereinafter abbreviated as UUP) submitted by Machica Mochtar who has performed sirri marriage. Based on the ruling of the CONSTITUTIONAL COURT No. 46/PUU-VIII/2010, that Article 43 paragraph (1) of law number 1 Year 1974 about marriage (State Gazette of the Republic of Indonesia Year 1974 number 1, an additional Sheet of the Republic of Indonesia Number 3019) states that "a child born outside marriage has only legal relationship with the mother and the mother's family," which in contrary with the Constitution of the Republic of Indonesia Year 1945 because it eliminates all legal relationships with the man who is proven legally or scientifically to have filiation.[1]

According to the Constitutional Court by article 43 paragraph (1) the UUP has no legal force. Based on the ruling, the position and rights of the child born in sirri marriage, including the right to marry within the marriage law and to obtain inheritance in accordance with the inheritance law, are the same with the child born in legal marriage.

Through ruling No. 46/PUU-VIII/2010, the Constitutional Court (MK) created a legal breakthrough which is quite phenomenal in the context of family law. This ruling gives birth to the pros and cons in society because votes can give opportunities to understand the existence of legal relationships between illegitimate children with the biological fathers. This material test was submitted by Machicha Mochtar, a former wife of the late Moerdiono, one the officials in the New Order.

The articles submitted for review are article 2 and article 43 of law No. 1 year 1974 about marriage. However, the COURT only granted one part and reject the other. The Constitutional Court conveyed the judge's decision and declared: first, granting the Petitioner's petition to the most; Second, Article 43 paragraph (1) of law number 1 Year 1974 about marriage (State Gazette of the Republic of Indonesia Year 1974 number 1, an additional Sheet of the Republic of Indonesia Number 3019) states "the children born outside marriage has only legal relationship with the mother and the mother's family," (Soebekti, 1985:10) is contrary to the Constitution of the Republic of Indonesia Year 1945 because it eliminates all legal relationships with the man legally and scientifically proven to have blood relation; Third, Article 43 paragraph (1) of law number 1 Year 1974 about marriage (State Gazette of the Republic of Indonesia Year 1974 number 1, an additional Sheet of 
the Republic of Indonesia Number 3019) states that "the children born outside marriage have legal relationship with the mother and the mother's family ", does not have binding legal force for eliminating legal relationships with men proven on the basis of science and technology and/or other evidence according to law have blood relations, so the paragraph should be read, "children born outside marriage has legal relations with the mother and the mother's family as well as with the father as a man who is proven on the basis of Science and technology and/or other proof according to law have blood relations, including relations with the father's family"; Fourth, the applicant to despise in addition and the rest; Fifth, Ordered to include this ruling in the news of the Republic of Indonesia as it should be.

The ruling of the CONSTITUTIONAL COURT No. 46/PUU-VIII/2010, read on Friday 17th February 2012, will arise various interpretations in line with the age of children outside marriage. The Republika daily, it can be known that with the use of extra-marital children became older, it's possible the emergence of diverse interpretations. The Republika daily newspaper, a day after the verdict was issued, wrote news under the title KUA worries the Constitutional Court's decision to encourage people to commit adultery. Minutes after the verdict was read out by the Chairman of the Court, public pro and con appear addressing the ruler of the decision which legally recognizes illigetimate relation with the biological father. [2]

Meanwhile, according to the Chairman of the MUI Amidan, the ruling of the CONSTITUTIONAL COURT was already a discussion derived from the law of marriage. Once an article that has been validated by the Constitutional Court, entered in the realm of jurisprudence, various opinions will arise. The Deputy Minister of religion, Nasaruddin Umar, said that he was ready to run the ruling of the CONSTITUTIONAL COURT. He also said that if the ruling of the CONSTITUTIONAL COURT ordered that children born outside marriage has legal relations with his father and his father's family, then the verdict should be applied.[3]

Many disappointing ruling party cannot compromise because the content is exactly the same as the ruling PA of South Jakarta which clearly states that the child born in consequence of the sirri marriage between Machicha Mochtar and late Moerdiono was still declared as illegitimate and there is no glimmer of hope for this ruling. Of course, the plaintiff of the party or the comparison has worked hard until the flavour is certainly pessimistic in an effort of Cassation related matters this will be fruitful as expected.
From the above description, it can be noted that the ruling of the CONSTITUTIONAL COURT No. 46/PUU-VIII/2010 on the Status of a child outside of marriage created varied responds by legal practitioners of particular judges.

\section{The Results of The Research AND The Discussion}

\section{A. The views of judges against the ruling of the CONSTITUTIONAL COURT}

The ruling of the CONSTITUTIONAL COURT No. 46/PUU-VIII/2010 spoken on 17 February 2012, was addressed and interpreted by the judge's PA and PTA in DKI Jakarta Province and Banten Province with diverse views. The view of the judges and the PTA, PA could be classified into three categories:

First, Judge PA and PTA received the ruling of the MK No. 46/PUU-VIII/2010 in the structure of the judiciary, where a decision is final and binding.

Both PA and PTA judges received the ruling of the CONSTITUTIONAL COURT No. 46/PUU-VIII/2010 under a condition. The ruling of the CONSTITUTIONAL COURT No. 46/PUU-VIII/2010 is interpreted and understood in the context of sirri marriage in accordance with the provisions of the religious (Islamic) according the provisions of article 2 paragraph (1), the Act of marriage of the year 1974 and not understood to mate "get-together added ".

Third, the PA and the PTA Judge who rejected the ruling of the CONSTITUTIONAL COURT No. 46/PUU-VIII/2010 argued that the ruling will open the opportunities of legalizing adultery. The judges decide to use contra legem principle in its implementation.

The judges who received the ruling of the CONSTITUTIONAL COURT No. 46/PUU-VIII/2010 without rejection are the judges of the PTA. They interpret the verdict also cover the children of adultery and not only limited to children of sirri marriage. The ruling of the CONSTITUTIONAL COURT No. 46/PUU-VIII/2010 include illegitimate children and children of adultery. Children of adultery have to meet their rights, should not be obscured, or get social sanction from the public. They were born innocent, and it was the parents who violate norm. Thus, the argument behind the ruling of the CONSTITUTIONAL COURT No. 46/PUU-VIII/2010 none other is part of the efforts to protect the rights of the child, as formulated in the Declaration of the human rights. This kind of attitude is in line with the objectives of Islamic law (maqâshid al-Syarî'ah), i.e. to maintain the continuity of his life (hifdz al-nafs) which in this case is the right to live of the child without any discrimination and pressure from any party. According to Hanafi, a child of adultery has the right to be dependent of his biological father. This understanding can be traced to the meaning of marriage. According to Hanafi, "the origin of the meaning of marriage in a language understood in the sense of promiscuity". 
However, according to Safi'i marriage is áqad, majazi', and is understood as covenant.

With reference to the views of Hanafi jurisprudence, judges of PTA Jakarta further stated, "the son of adultery may be dependent to his biological father". To reaffirm this view, Judges of PTA Jakarta mention the book al-Radd Mukhtâr (one of the books of Fiqh in Hanafi written Ibn ' Abidin). The judges then declared "in the book al-Radd Mukhtâr stated, children of zina relationships are forbidden by her biological father, including the responsibilities of the civil code".[4]

In search of researchers, based on the fatwas issued by MUI,[5] $]^{\mathrm{i}}$ stated as follows: "the opinions of the majority view of Hanafiyyah, Malikiyyah, Shaafa'is and Hanbalis jurisprudence stated that the principle of determination is not allowed because a legal relationship is a valid marriage". In addition to a valid marriage, since there are no legal consequences of an illegitimate relationship, and thus a child of zina is depended on his mother, not on the biological father, as set forth in a few excerpts below:

\section{1) Ibn Hajar al-'Asqalani:}

Meaning: it was narrated from Imam Syafe'i there are two notions about the meaning of the Hadith "the boy becomes the right owner of mattress/husband".

First: the children became owners of the mattress/husband as far as he does not disown. When the owner of a mattress/husband denies the child with the procedure recognized its validity in the Sharia, as does Li'an, then the child is not as his son.

Second: in case of dispute (related ownership of children) between the owner of a mattress/husband and a man raped his wife/slave women, the child became the owner of the right mattress/husband.

As the meaning of "for adulterer is the rock" is that the male adulterer was blocked and despaired, the meaning of the word al-' ahar by using two fathah (on the letter ' ain and ha ') is adultery. It is argued that the word is used for cohabitation. Therefore, the meaning of desperation here is that the male adulterer is not forbidden to get right over children born from adultery. The selection of the word despair here in accordance with the traditions of the Arabs who stated, "her rock" or "Rock" in his mouth made the person who has loss his hope. It is argued that the notion of rock here is the punishment of stoning. Imam Nawawi stated that such opinion is weak because the penalty of stoning the adulterer create deserved only muhsan (married). On the other hand, the Hadith is not intended to explain the law of stoning, but intended to simply deny the rights of the child of adultery. Hence Imam Subki stated that the first opinion is more appropriate with the Hadith, because in general the desperation (from getting the right child) covers the whole group of Adulterers (muhsan or not a muhsan).
B. the opinion of Imam al-Sayyid al-Bakry in the book "I'anatu al-Thalibin" juz 2 page 128 as below:

Meaning: Son of adultery is not descended from the father, but from his mother.

So, the statement of PTA Jakarta judges that "the results of adultery relationship forbidden by her biological father, including the responsibilities of civility." This opinion does not represent the opinion of Ibn Taymiah Ibn Abidin.

According to the researchers, the refusal of the North Jakarta PA judge on the subjective view of the issue led to religious norms embracing the views of the majority judges namely jurisprudence, where the recognition of the legal status of biological civic relations with the father would coincide against the acknowledgement of fornication and adultery. The subjective view of the issue caused religious norms embrace the views of majority of the justices namely jurisprudence, where recognition of the legal status of the biological civility relationship with his father will impact against the recognition of fornication and adultery, which is considered sacred. In addition, it will create technical problems because there will be many lawsuits or legal acknowledgement. Moreover, there will be opportunities for falsification of DNA test results.

\section{CONSIDERATION OF THE JUDGES IN THE IMPLEMENTATION OF THE RULING OF THE CONSTITUTIONAL COURT}

In General, the judge agreed that the ruling of the CONSTITUTIONAL COURT is final and binding for all of the judiciary in General. But in its implementation, the judge will use his independence to interpret the ruling. [6] $]^{\text {ii }}$

In the appeal court case of Machicha Mochtar lawsuit, the the Tribunal Judges of PTA Jakarta rejected the appeal. The Tribunal Judge fully approved South Jakarta first rate PTA ruling. The Tribunal Appeals Judge added that the provisions of of article 2 paragraph (1) and paragraph (2) are an integral part, so that every citizen is obligated to fulfill the requirements of the recording according to the prevailing laws and regulations in Indonesia, let alone the deceased Moerdiono was a state official who must example of compliance with the applicable regulations. In addition, Moerdiono also violated the provisions of article 3 of the imperative permission specified polygamy trial.

The provisions of article 3 appropriates with rules of Fiqh in Al-Asybah wa al-Nadhair:

It means: "Government Clearance over the people is in accordance with the benefit".

Several judges declared their consent and others expressed disagreement with the decision. PA Tigaraksa judge, for example, said the judge's "right of discretion" in deciding the matter is not an sich in the implementation of the Act, so that the judge could make different decision from the 
Constitutional Court's decision, although he acknowledged that the Court's decision is final and binding. Thus, children outside marriage will receive a legitimate relationship with his biological father after the parents' marriage is ratified in the Court of Appeal. This mindset comes from the understanding that the provisions of article 2 paragraph (1) and (2) are inseparable. The PA judge said:

Thus, the South Jakarta PA and PTA judges interpreted the article 2 paragraph (1) and (2) as a whole. This is in contrast to the consideration of the Tribunal Constitutional Court Justice in which the validity of the marital status of his parents is still debateable.

The consideration of the constitutional Judges is as follows "... the law must provide protection and legal certainty over the status and rights of every child born, including to a child born to parents whose marriage legality is still at issue"

The opinion of the Constitutional Court above provides enough significant meaning for the future of children born outside marriage. Because the idea of the above consideration is that a child's status and position is separated from all the parent's deeds and actions. This means that the State must protect the rights attached to the child, though the validity of the parents' marriage is disputed.

The substance of the verdict of the COURT is solely looking at the issue in the context of the protection of children in accordance with Article 28 B of paragraph (2) and section $28 \mathrm{D}$ paragraph

(1) of the 1945 CONSTITUTION and Act No. 39-year 1999 about human rights. Article 28 B of paragraph (2) stated that "every child has the right to live, grow and develop as well as the right to protection from violence and discrimination." Whereas article 28 D paragraph (1), "everyone has the right to the recognition, protection and assurance of legal certainty, fair and equal treatment before the law." While according to the provisions of article 1 point (3) of LAW Number 39 on human rights that the definition of "discrimination" is:

Discrimination is any limitation, harassment, or exclusion directly or indirectly based on the distinction of human beings on the basis of religion, tribe, race, ethnic, group, class, social status, economic status, sex, language, belief politics, which resulted in a reduction or elimination of irregularities, the recognition, implementation or use of the human rights and basic freedom in the life of the individual as well as collective good in the areas of political, economic, legal, social, cultural, and the lives of others.

Later the tenth part of the Act explains the rights of the child as either human or citizen. In articles related to the rights of children in the constitution and the law, there is no distinction between the right of a legitimate child of illegitimate child. So, what the court decided in relation with Article 43 of the marriage law of 1974 considers the the provisions of the constitution and related laws.

In the criminal code itself, a child outside marriage will only have a civil relationship with the biological father if the father acknowledged him. Article 280 of the civil code mentions KUH that with the recognition of the child outside marriage, the child will have civil relationship with the biological mother and father. The recognition of the child outside marriage can be done by an authentic deed or birth certificate.

Such recognition amy also be made by a deed made by a civil registry officer and registered on the register of birth in accordance with the day of signature of the admission. The recognition should be noted in the margin of the birth certificate if the birth certificate exists. But when recognition is made by other authentic deed, the person has the right to request that it be listed in the margin of the birth certificate.

The principle of the recognition of the child outside marriage adopted by Civil Code is absolute because a child born outside marriage is based on the principle of the law of the West does not have a civil relationship with his father and mother. This is in contrast with the principle of Marriage Law No. 1 year 1974 and compile of Islamic law that the child outside the civil relationship is automatically depended with the mother.

As for the registration procedure of child recognition outside marriage pursuant to article 49 of LAW Number 23 of the year 2006 regarding Population Administration covers:

a) parents report it at least 30 days from the date of the Child Recognition letter by the father and mother.

b) The obligation to report as referred to in paragraph (1) is excluded for parents whose religion does not permit the recognition of a child outside marriage.

c) Based on the reports referred to in paragraph (1) the Civil Registry official records the deed of child recognition and issues the Certificate of Recognition of the child.

The civil code related to child outside marriage implies that child may request an alimentation right from his biological father or hadhanah in Islamic law. Those rights have been regulated in chapter X of article 45 up to Article 49 of the ACT of marriage of the year 1974 in the form of a living, education, guardianship, inheritance, and so on.

\section{REFERENCES}

[1] The sirri marriage in the sense of a legitimate marriage is based on the terms and the pillars of marriage as Islamic jurisprudence. however, it is not recorded in the book of registration of marriage

[2] http//www.detik. com/Post the ruling of the Constitutional Court, Wamenag: children outside of marriage Could Be an act of birth, date 17/02/2012

[3] http//www.detik.com/Post the ruling of the Constitutional Court, Wamenag: children outside of marriage Could $\mathrm{Be}$ an act of birth, date 17/02/2012

[4] Interview with Edi Riadi, judge of the PTA at once Vice Chairman of the PTA.

[5] The MUI number: 11 year 2012 about the position of the Child's treatment of adultery and Results against him. 
[6] Interview with judge PA Jakarta Timur, Jakarta Barat, Jakarta Utara, Tigaraksa and Tangerang.

[7] Asqalani Ibn Hajar al-, Fath al-Bari, (Beirut: Dar al-Ma'rifah), juz X

[8] Asshiddiqie, Jimly, "Kedudukan Mahkamah Konstitusi Dalam Struktur Ketatanegaraan Indonesia”, Makalah dipresentasikan dalam Kuliah Umum di Fakultas Hukum Universitas Sebelas Maret, Surakarta, Kamis, 2 September, 2004. Diakses dari www.jimlyasshiddiqie.com

[9] Baihaqî, al-, Abû Bakr Ahmad bin al-Husein, Sunan al-Baihaqi alKubrâ, (Makah: Maktabah Dâr al-Baz, 1994), Editor: Muhammad Abdul Qâdir 'Atha. juz ke-7, hal. 443

[10] Bakr al-, Ianah al-Thalibin (Beirut: Dar al-Fikr, t.th),

[11] Bukhârî, Abû Abdillah Muhammad bin Isma'il al-, al-Bukhâri bi Hasyiah al-Sindy, (Beirut: Dâr al-Fikr, 1995), juz ke-16.

[12] Chatib, Rasyid, "Anak Lahir Diluar Nikah (Secara Hukum) Berbeda Dengan Anak Hasil Zina Kajian Yuridis Terhadap Putusan MK NO. 46/PUU-VII/2012", Makalah disampaikan dalam Seminar Status Anak di Luar Nikah dan Hak Keperdataan lainnya, pada tanggal 10 April 2012, di IAIN Walisongo Semarang.

[13] Dawud, Abu, Sunan Abi Dawud, (Beirut: Dar al-Fikr, 2001), jus ke-6, hal, 182.

[14] Kuspraningrum, Emilda, Kedudukan dan Perlindungan Anak Luar Kawin, h. 26. Ensiklopedi Hukum Islam, Nasab, Editor Abdul Azis Dahlan, (Jakarta: Ichtiar Baru Van Hoeve, 1996), cet.ke-1, jilid ke-4.

[15] Fuad Thohari, Tafsir Ilmi, Materi Pembekalan LDII, di Jakarta; Himpunan Fatwa MUI, (Jakarta: Erlangga, 2011), h. 236.
[16] Ibn Jarir al-Thabari, Tafsir al-Thabari, (Beirut: Dar al-Fikr, 2000), juz ke-21.

[17] Ibn Mâjah, Sunan Ibn Mâjah, (Beirut: Dâr al-Fikr, tth.), editor: Muhammad Fuad Abdul Baqi, jus ke-8,

[18]

[19] Nawawi, Abu Zakariya Yahya bin Syaraf al-, Raudlat al-Thalibin wa 'Umdat al-Muftin, (Beirut: Dar al-Fikr, tth.), juz ke-3

[20] Pound, Roscou, Pengantar Filsafat Hukum: Buku III. Penerjemah Moh. Radjab, (Jakarta: Bharata, 1963).

[21] Shawi, Abu al-'Abbas Ahmad bin Muhammad al-Hasyiah al-Shawi 'ala Syarh al-Shaghir, (Mesir: Dar al-Ma'arif, 2001), jus ke-8.

[22] Sumadi, Ahmad Fadlil, "Mahkamah Konstitusi dan Putusan Judicial Review UU Perkawinan", Makalah, tidak diterbitkan,

[23] yamsul Anwar dan Isak Munawar, "Nasab Anak di Luar Perkawinan Paska Putusan Mahkamah Konstitusi No. 46/PUU-IIIV/2010 Tanggal 20 Februari 2010 Menurut Teori Fikih dan Perundang-undangan".

[24] Syarifuddin, Amir, Hukum Perkawinan Islam Di Indonesia Antara Figh Munakahat dan Undang-undang Perkawinan, Jakarta: Kencana, 2007

[25] Syathibi, al-Muwafaqat fi Ushul al-Syari'ah, (Beirut: Dar al-Kutub alIslamiyah, t.t), jus ke-2, hal. 12-23.

[26] Taufiki, Muhammad, Konsep Nasab, Istilhaq, dan Hak Perdata Anak Luar NIkah, (Ahkam: Jurnal Ilmu Syari'ah, Vol XII, No. 2 Juli 2012). 